\title{
DEVELOPMENT OF TEACHING MATERIALS IN WRITING DESCRIPTIVE TEXTS OF VOCATIONAL SCHOOL STUDENTS
}

\author{
Risnawaty ${ }^{1}$, Yulia Arfanti ${ }^{2}$, Milisi Sembiring ${ }^{3}$, Roswani Siregar ${ }^{4}$, \\ Heni Subagiharti ${ }^{5}$ \\ 1, 2 Muslim Nusantara Al-Washliyah Universitity, Medan, Indonesia \\ ${ }^{3}$ Universitas Methodist Indonesia, Medan, Indonesia \\ ${ }^{4}$ Universitas Al Azhar Medan, Indonesia \\ ${ }^{5}$ Universitas Asahan, Kisaran, Indonesia \\ E-mail: risnawaty@umnaw.ac.id
}

Received: 2021-01-06

Accepted: 2021-04-06

\begin{abstract}
The objective of the study is to develop the teaching materials in writing descriptive texts in Grade X students of SMK Binaan UMN Al-Washliyah 3, Medan. The study is conducted by the Development Research method, and the evaluators are the instructors of the Indonesian Subject (specific instructors), and the subjects are Grade $X$ students. Pre-test and post-test are done to find out the effectiveness of the result. The result of the pretest shows that the average score is $67 \%$ with the category of satisfactory; the result of the post-test shows that the average score is $85 \%$ with the category of distinction. The process of developing teaching materials includes three aspects of assessment: 1) teaching materials, 2) presentation, and 3) language structure. The validation of material experts includes content with an average score of $4.9 \%$ and a percentage of $82.2 \%$ with the category of distinction. The feasibility of presenting teaching materials has an average score of $113 \%$ with the category of distinction, and the language element has an average score of $11.4 \%$ with the category of distinction. The conclusion indicates that the design for developing teaching materials of descriptive texts by using a scientific approach in the subject of Indonesian is very effective.
\end{abstract}

Keywords: Developing, Scientific Approach, Descriptive Texts, Teaching Materials, Vocational School.

\section{Introduction}

The subject of Indonesian is a compulsory one which has to be studied in either public or private schools. It is specified in the Curriculum of 2013, which prioritizes text basedmaterials. One of the subjects in the curriculum of 2013 is writing. According to Kurniasih and Rahmawati (2018) in the process of developing writing materials, the teachers should be familiar with learning objectives, organizing the structure of the book, writing and selecting essay models, creating tasks, designing grammatical focus and vocabulary exercise, and completing the appendix. Yamin,(2019) adds that the general weakness the students have in writing paragraphs deals with a topic sentence in which the learners have a problem in 
Development of Teaching Materials in Writing Descriptive Texts of Vocational School Students, Risnawaty, Yulia Arfanti, Milisi Sembiring, Roswani Siregar, Heni Subagiharti

determining the topic sentence correctly. Furthermore, (Riwayatiningsih, 2019) explains that writing is the most difficult skill in the process of learning a language; it is caused by a lack of idea.

Texts are the system that is used to give information. There are some types of text narrative, expositional, explanatory, persuasive, argumentative, and descriptive texts. Each of these texts has its own characteristics. The descriptive text has been taught at schools, and the development of teaching materials in writing descriptive texts by using the scientific approach has not yet been taught in Grade X students of SMK Sekolah Binaan UMN. Talking about descriptive text, teachers should be familiar with the process of describing context to be a descriptive text. A text can also be found as what (Sembiring, Milisi. Panggabean, 2018) is discussed in their studies. The creativity of the students is really needed to increase their writing skills. The students should try to be familiar with several ways to advance their ways of thinking. The condition of writing class is like a graveyard, students do their writing in a silent way, while the teacher monitors their activities and helps some students who ask about vocabularies. (Indriani, 2017)

The authors believe that in writing descriptive text, it is quite difficult for the students if there is no creativity to increase their vocabularies. The authors know that lack of vocabularies is one of factors that makes students hard to create in the writing process. Therefore the authors make creative ways for students to increase their ability. The students need to have a model of creating a writing activity. It is also explained that the educational world is inseparable from the learning model applied in the classroom(Palupi et al., 2020). This is also a major factor in determining the success of educational goals. Therefore the teacher and students should have the same orientation in the process of learning. It is explained that a teacher with good teaching readiness behaviors could make students trust that the teacher is really capable of teaching the students (Wijaya, 2017). Furthermore, experimenting and associating are considered to be good enough while communicating is considered to be well implemented. The scientific approach is effective in making the students actively involved in the classroom activities so that their speaking and listening skills can be improved (Zaim, 2017). Education is becoming commonsense to consider programming skills as important as other fundamental skills, math, reading, and writing(Silva \& Silveira, 2020). Many explorations have been conducted in improving teaching English skills, (Bochkareva, et all., Astutik, et all, 2020).

The objective of the research was to explain the effectiveness and the process of developing teaching materials by using a scientific approach and by assessing the media of teaching, which include validity, effectiveness, and practicing to teach how to write descriptive texts. It is known that teaching material is a set of lesson materials which are referred to the curriculum 2013 in order to achieve specified competency standard and basic competency.

\section{Literature Review}

The teacher must know the student's activity in learning how to write the description of the text by applying the problem based on the learning method of the students in a class. The teacher must observe the communicative relationship between students and teacher as well as the students with others.

According to Masrukhah (2017), descriptive material is potentially helpful for students' activities in encouraging students' literacy skills through giving appropriate materials for 
reading and writing. Besides, (Ningsih \& Fitrawati, 2014) explain that writing is required not only for a message of a paragraph especially for a descriptive text, but it should convey the meaning of the text to the reader. Furthermore, (Sundana, 2017) explains that writing can be improved by the use of appropriate grammar or vocabulary such as the correct use of tenses, concords and modifiers. Translation also has a potential process in teaching writing descriptive text. (Khasanah, 2019) emphasizes that the teacher should use mixed languages, English-Indonesia so that students know and understand the lessons given. According to (Sarma, Devita. Rosa, Rudi, 2014) double entry diary is helpful in developing students' ability for writing descriptive text.

\section{Research Method}

The research is conducted by the development method, which is also called Research and Development ( $R \& D$ ) method. It is a method that is used to yield certain products and product testing, as has been pointed out by Sugiono (2016), a method that is based on adaptation to a procedure. (Syaodih et al., 2009) states that Research and Development method is a process to develop a new processor to complete an existing product. The scientific approach emphasizes the students to be active in asking, arguing, and accommodating on what is being taught and describing it through their writing, which is called descriptive text, according to curriculum 2013.

Furthermore, Risnawaty et al., (2020) propose that the explanation for the cultural term in one language should be done to get a close meaning in another language. In the process of explaining a cultural term in a language, the authors believe that the process of writing done by students will advance their competence in writing skills.

In addition,researchers also use the 'explication de texte' approach or known as the term 'textual approach' by analyzing text or manuscripts. Therefore, this research can also be called descriptive research because this research relies onthe development of teaching materials in writing descriptive texts by using the scientific approach that has not yet been taught in Grade X students of SMK Sekolah Binaan UMN.

\section{Results and Discussion}

There are two findings in this research on developing teaching materials in writing descriptive texts by using a scientific approach:

1. Effectiveness in developing teaching materials in writing descriptive texts by using a scientific approach.

In this case, the researchers have to find out the previous teaching of writing descriptive texts, the scores obtained by the students in their writing works, and their capability of writing descriptive texts by performing a pre-test to find out what they have achieved. After getting their achievement, the researchers could develop the teaching media. In this case, the researchers use the Development Research method for writing descriptive texts by using a scientific approach.

The result of the pre-test shows that the students' scores are not satisfactory since they are not interested in the lecture model (conventional model) in which the teachers do not emphasize the five elements as they are suggested by the curriculum 2013 (observing, asking, attempting, associating, and documenting. The result of the pre-test could be seen in the Table below. 
Table 1. Pre- TestAnalysis of Descriptive Text without Using Scientific Approach

\begin{tabular}{|c|c|c|c|c|c|c|c|}
\hline \multirow{2}{*}{ No } & \multirow{2}{*}{ Samples } & \multicolumn{2}{|c|}{ Pre- Test Analysis of Descriptive Text } & Concluding & \multicolumn{2}{|c|}{ Scores (\%) } \\
\cline { 3 - 8 } & $\begin{array}{c}\text { Observing } \\
\text { Themes 20 \% }\end{array}$ & $\begin{array}{c}\text { Asking 20 } \\
\text { \% }\end{array}$ & $\begin{array}{c}\text { Processing } \\
\text { Data 30\% }\end{array}$ & $\mathbf{3 0 \%}$ & Total & Category \\
\hline 1 & 1 & 12 & 12 & 18 & 18 & 60 & Adequate \\
\hline 2 & 2 & 14 & 14 & 21 & 21 & 70 & Satisfactory \\
\hline 3 & 3 & 13 & 13 & 22,5 & 22,5 & 71 & Satisfactory \\
\hline 4 & 4 & 12 & 12 & 21 & 18 & 60 & Adequate \\
\hline 5 & 5 & 16 & 16 & 24 & 24 & 80 & Distinction \\
\hline 6 & 6 & 16 & 16 & 24 & 24 & 80 & Distinction \\
\hline 7 & 7 & 12 & 12 & 24 & 24 & 72 & Satisfactory \\
\hline 8 & 8 & 12 & 12 & 18 & 18 & 60 & Adequate \\
\hline 9 & 9 & 14 & 14 & 21 & 21 & 70 & Satisfactory \\
\hline 10 & 10 & 14 & 14 & 21 & 21 & 70 & Satisfactory \\
\hline 11 & 11 & 16 & 16 & 24 & 24 & 80 & Distinction \\
\hline 12 & 12 & 14 & 17 & 21 & 21 & 70 & Satisfactory \\
\hline 13 & 13 & 14 & 14 & 21 & 21 & 70 & Satisfactory \\
\hline 14 & 14 & 16 & 16 & 24 & 24 & 80 & Distinction \\
\hline 15 & 15 & 14 & 14 & 21 & 21 & 70 & Satisfactory \\
\hline 16 & 16 & 16 & 16 & 24 & 24 & 80 & Distinction \\
\hline 17 & 17 & 16 & 16 & 24 & 24 & 80 & Distinction \\
\hline 18 & 18 & 14 & 14 & 24 & 24 & 60 & Adequate \\
\hline 19 & 19 & 14 & 14 & 24 & 24 & 60 & Adequate \\
\hline 20 & 20 & 14 & 14 & 24 & 24 & 60 & Adequate \\
\hline & & & & & & 1.403 & \\
\hline
\end{tabular}

Average Score $=70.15$

The Number of Data $=1403$

Table 1 above indicates that teaching descriptive texts without using the scientific approach is not very effective because the percentage of scores indicates that $30 \%$ of the respondents get fair grades, $40 \%$ satisfactory grades, and $30 \%$ of them distinction grades. Based on the scores obtained by the respondents, it is found that they are not very interested in the conventional teaching method, so that it is necessary to develop it. Based on the fact above, the researchers develop it by using Research and Development(R\&D) Theory, using a scientific approach, as it is shown below:

Table 2. Post - Test. Writing Descriptive Texts Using Scientific Approach

\begin{tabular}{|c|c|c|c|c|c|c|c|}
\hline \multirow{2}{*}{ No } & \multirow{2}{*}{ Samples } & \multicolumn{2}{|c|}{ Post - Test Writing Descriptive Texts } & Concluding & \multicolumn{2}{|c|}{ Scores } \\
\cline { 3 - 8 } & $\begin{array}{c}\text { Observing } \\
\text { Theme 20 \% }\end{array}$ & Asking 20 \% & $\begin{array}{c}\text { Processing } \\
\text { Data 30\% }\end{array}$ & $\mathbf{3 0 \%}$ & Total & Category \\
\hline 1 & 1 & 16 & 16 & 24 & 24 & 80 & Distinction \\
\hline 2 & 2 & 15 & 15 & 24 & 24 & 80 & Distinction \\
\hline 3 & 3 & 16 & 16 & 24 & 24 & 80 & Distinction \\
\hline 4 & 4 & 15 & 15 & 24 & 24 & 78 & Satisfactory \\
\hline 5 & 5 & 16 & 16 & 24 & 24 & 80 & Distinction \\
\hline
\end{tabular}


Language Literacy: Journal of Linguistics, Literature and Language Teaching

Volume 5, Number 1, pp: 106-116, June 2021

e-ISSN: 2580-9962 | p-ISSN: 2580-8672

DOI: $10.30743 / I I . v 5 i 1.3369$

\begin{tabular}{|c|c|c|c|c|c|c|c|}
\hline 6 & 6 & 16 & 16 & 24 & 24 & 80 & Distinction \\
\hline 7 & 7 & 16 & 16 & 24 & 24 & 80 & Distinction \\
\hline 8 & 8 & 16 & 16 & 24 & 24 & 89 & Distinction \\
\hline 9 & 9 & 16 & 16 & 24 & 24 & 80 & Distinction \\
\hline 10 & 10 & 15 & 15 & 24 & 24 & 80 & Distinction \\
\hline 11 & 11 & 16 & 16 & 24 & 24 & 80 & Distinction \\
\hline 12 & 12 & 14 & 15 & 21 & 21 & 78 & Satisfactory \\
\hline 13 & 13 & 16 & 16 & 24 & 24 & 80 & Distinction \\
\hline 14 & 14 & 16 & 16 & 24 & 24 & 80 & Distinction \\
\hline 15 & 15 & 15 & 15 & 24 & 24 & 78 & Satisfactory \\
\hline 16 & 16 & 16 & 16 & 24 & 24 & 80 & Distinction \\
\hline 17 & 17 & 16 & 16 & 24 & 24 & 80 & Distinction \\
\hline 18 & 18 & 16 & 16 & 24 & 24 & 80 & Distinction \\
\hline 19 & 19 & 15 & 15 & 24 & 24 & 80 & Distinction \\
\hline 20 & 20 & 15 & 15 & 24 & 24 & 80 & Distinction \\
\hline \multicolumn{5}{|c|}{ TOTAL } & \multicolumn{3}{|c|}{1.603} \\
\hline
\end{tabular}

The Table 2 above indicates that the average score $\quad=1.603 / 20=80.15 \%$

From the table 2 above, it could be concluded that the post-test gets the average score of $80.15 \%$. Analysis of developing descriptive text by using the scientific approach is very effective since the result of the post-test shows that the students are very interested in scientific teaching media because they could exercise their observation, asking questions, processing data, and concluding.

2. Assessment on the Process of Developing Teaching Materials by using Scientific

Approach.

The developing teaching materials become the guideline for students for their competency, which has to be mastered by teachers as an important evaluation device of teaching in implementing education. The core competence (CC) and basic competence (BC) are shown in table 3 . The process of developing teaching materials includes three aspects of feasibility: 1) material/content feasibility, 2) presentation feasibility, and 3) language feasibility.

Table 3. Content/Material Feasibility Data of Validation of Professional Teachers Stage 1 and Stage 2 in the Aspects of Content/Material Feasibility

\begin{tabular}{|c|c|c|c|}
\hline \multirow{2}{*}{ No } & \multicolumn{1}{|c|}{ Assessment Indicators } & \multicolumn{2}{c|}{ Scores (\%) } \\
\cline { 3 - 4 } & $\begin{array}{c}\text { Stage 1 } \\
\text { (pre-revision) }\end{array}$ & $\begin{array}{c}\text { Stage 2 } \\
\text { (post-revision) }\end{array}$ \\
\hline 1 & $\begin{array}{l}\text { Presenting teaching materials containing } \\
\text { teaching materials of the subjects which support } \\
\text { the achievement of CC and BC }\end{array}$ & 4 & 5 \\
\hline 2 & $\begin{array}{l}\text { Explanation of concept, definition, procedure, } \\
\text { examples, and exercises in a module according to } \\
\text { the need for teaching materials of the subjects } \\
\text { which support the achievement of CC and BC. }\end{array}$ & 3 & 4 \\
\hline 3 & Teaching materials specified in a module can & 3 & 4 \\
\hline
\end{tabular}




\begin{tabular}{|c|c|c|c|}
\hline & $\begin{array}{l}\text { encourage students to know ideas, to identify } \\
\text { and to explain them, to construct new } \\
\text { knowledge, and to implement KI and KD. }\end{array}$ & & \\
\hline 4 & $\begin{array}{l}\text { The presented teaching materials should be } \\
\text { accurate and correct so that they can help } \\
\text { achieve CC and KD. }\end{array}$ & 4 & 4 \\
\hline 5 & $\begin{array}{l}\text { The design of teaching materials in a module } \\
\text { should be accurate and able to be formulated so } \\
\text { that students will not be confused and wrong in } \\
\text { interpreting them. }\end{array}$ & 3 & 4 \\
\hline 6 & $\begin{array}{l}\text { The procedure in the module should be } \\
\text { formulated accurately so that it will not be } \\
\text { systematically interpreted. }\end{array}$ & 3 & 4 \\
\hline 7 & $\begin{array}{l}\text { Teaching materials should contain concepts, } \\
\text { principles, procedures, or formula, aided by } \\
\text { accurate examples, facts, illustrations. }\end{array}$ & 3 & 4 \\
\hline 8 & $\begin{array}{l}\text { Questions should be clear according to the } \\
\text { teaching materials so that students can answer } \\
\text { them accurately. }\end{array}$ & 2 & 5 \\
\hline 9 & $\begin{array}{l}\text { Teaching materials presented in the module } \\
\text { should be in line with the development of } \\
\text { current science and technology. }\end{array}$ & 3 & 5 \\
\hline 10 & $\begin{array}{l}\text { Explanation, examples, and exercises in the } \\
\text { module should have renewal values. }\end{array}$ & 3 & 4 \\
\hline 11 & $\begin{array}{l}\text { Teaching materials presented should be able to } \\
\text { encourage students to draw conclusions. }\end{array}$ & 3 & 4 \\
\hline 12 & $\begin{array}{l}\text { Teaching materials should be able to affect } \\
\text { students to solve problems. }\end{array}$ & 3 & 5 \\
\hline 13 & $\begin{array}{l}\text { The available teaching materials in the module } \\
\text { should be related to the concepts. }\end{array}$ & 3 & 5 \\
\hline 14 & $\begin{array}{l}\text { The available teaching materials in the module } \\
\text { should be communicative so that they can } \\
\text { explain contextually the problems being learned } \\
\text { by students. }\end{array}$ & 4 & 5 \\
\hline 15 & $\begin{array}{l}\text { The presented teaching materials in the module } \\
\text { should be explanations and exercises so that they } \\
\text { can help explain their implementation in daily } \\
\text { life. }\end{array}$ & 3 & 4 \\
\hline 16 & $\begin{array}{l}\text { Teaching materials in the module should be } \\
\text { interesting so that students can learn the module } \\
\text { joyfully and effectively. }\end{array}$ & 3 & 4 \\
\hline 17 & $\begin{array}{l}\text { Assignments available in the module should be } \\
\text { able to train students to get information from } \\
\text { various sources. }\end{array}$ & 3 & 4 \\
\hline 18 & $\begin{array}{l}\text { The module should contain the materials for } \\
\text { evaluation, which can measure students' } \\
\text { capacity. }\end{array}$ & 4 & 5 \\
\hline
\end{tabular}




\begin{tabular}{|c|l|c|c|}
\hline 19 & $\begin{array}{l}\text { Teaching materials in the module should be } \\
\text { interesting. }\end{array}$ & 3 & 4 \\
\hline 20 & $\begin{array}{l}\text { Teaching materials presented in the module } \\
\text { should be able to be formulated clearly }\end{array}$ & 3 & 4 \\
\hline & Total & 63 & 87 \\
\hline & Average Score & $3,15 \%$ & $4.35 \%$ \\
\hline & Category & Adequate & Distinction \\
\hline
\end{tabular}

The table 3 above indicates that the average Content/material feasibility has the scores of 4.35 with a percentage of $87 \%$ with the category of distinction. Meanwhile, before using a scientific approach, the average score is low (3.15), with the percentage of $63 \%$ with the category of adequate. The Table above indicates that there is a significant increase after the scientific approach has been developed.

\section{Feasibility of Teaching Materials}

Presenting teaching materials is the strategy of selecting teaching materials that will be presented and the behavior toward the teaching materials which will be presented to students. The feasibility of teaching materials for Grade $\mathrm{X}$ students of SMK Bisnis of Madrasah Binaan UMN Al-Washliyah can be seen in the Table below:

Table 4. Data of the Validation of Skilled Teachers of Stage 1 and Stage 2 in the Aspect of Presentation Feasibility

\begin{tabular}{|c|c|c|c|}
\hline \multirow[b]{2}{*}{ No } & \multirow[b]{2}{*}{ Assessment Indicators } & \multicolumn{2}{|c|}{ Scores } \\
\hline & & $\begin{array}{l}\text { Stage } 1 \\
\text { (Pre- } \\
\text { Revision) }\end{array}$ & $\begin{array}{c}\text { Stage } 2 \\
\text { (Post- } \\
\text { Revision) }\end{array}$ \\
\hline 1 & $\begin{array}{l}\text { Every chapter is equipped with pictures, illustrations, } \\
\text { sentences, introduction, and conclusion }\end{array}$ & 2 & 4 \\
\hline 2 & $\begin{array}{l}\text { Presenting teaching materials in the module should } \\
\text { be in line with thinking linearly to make students } \\
\text { understand. }\end{array}$ & 3 & 5 \\
\hline 3 & $\begin{array}{l}\text { Explanation of substances in chapters (reflected in } \\
\text { the number of pages) should be presented } \\
\text { proportionally by always considering KI and KD }\end{array}$ & 4 & 4 \\
\hline 4 & $\begin{array}{l}\text { Explanation in the module should be interactive and } \\
\text { participative so that students will be motivated to } \\
\text { learn independently. }\end{array}$ & 3 & 5 \\
\hline 5 & $\begin{array}{l}\text { Explanation and discussion of teaching materials in } \\
\text { the module should accommodate active and } \\
\text { enjoyable learning. }\end{array}$ & 3 & 5 \\
\hline 6 & $\begin{array}{l}\text { Explanation of teaching materials should be able to } \\
\text { encourage students to think critically, creatively, and } \\
\text { innovatively. }\end{array}$ & 3 & 5 \\
\hline 7 & $\begin{array}{l}\text { The introduction in the module should be presented } \\
\text { clearly. It should include a foreword, Direction, Table } \\
\text { of Contents and/or List of Symbols, or Notation. }\end{array}$ & 3 & 5 \\
\hline
\end{tabular}




\begin{tabular}{|c|l|c|c|}
\hline 8 & $\begin{array}{l}\text { In the content, the presentation of teaching } \\
\text { materials in the module should use pictures, } \\
\text { illustrations, tables, references, exercises, and } \\
\text { summaries. }\end{array}$ & 4 & 4 \\
\hline 9 & $\begin{array}{l}\text { The last part of the module should have References, } \\
\text { an index, a list of terms, and directions for doing the } \\
\text { exercises. }\end{array}$ & 3 & 4 \\
\hline & Total & 28 & 51 \\
\hline & Presentation & $62.2 \%$ & $5.67 \%$ \\
\hline & Category & Fair & Very Good \\
\hline
\end{tabular}

The table 4 above shows the average score of 4.5 with a percentage of $113.4 \%$ with the category of distinction. Before it is developed by using a scientific approach, the average score is 3.11 , with the percentage of $62.2 \%$ with the category of adequate. Therefore, it could be concluded that there is a significant increase in the average score after the scientific approach has been developed.

Indicators of assessment for the feasibility of language field consist of three elements: 1) the language used in the texts should be easily understood by students, 2) the language should be communicative, and 3) the language used should be clear. The feasibility of the language field can be seen in the Table below.

Table 5. Feasibility in Language Field Data for the Validation of Skilled Teachers in Stage1 and Stage 2 In the Elements of Language Feasibility

\begin{tabular}{|c|c|c|c|}
\hline No & Indicators for Assessment & $\begin{array}{c}\text { Stage I } \\
\text { (Pre-Revision) }\end{array}$ & \begin{tabular}{|c|} 
Stage 2 \\
(Post- Revision)
\end{tabular} \\
\hline 1 & $\begin{array}{l}\text { The language used to explain teaching materials } \\
\text { in the module should be in line with students' } \\
\text { capacity. }\end{array}$ & 3 & 4 \\
\hline 2 & $\begin{array}{l}\text { The language used in the module should be in } \\
\text { line with students' social-emotional capacity. }\end{array}$ & 3 & 5 \\
\hline 3 & $\begin{array}{l}\text { The module should look attractive since it uses } \\
\text { language, which is clear, on target, and not } \\
\text { ambiguous so that students will be easy to } \\
\text { understand it. }\end{array}$ & 3 & 4 \\
\hline 4 & $\begin{array}{l}\text { Words and sentences in the module should be } \\
\text { easy to understand so that they will be } \\
\text { motivated to read it completely. }\end{array}$ & 3 & 4 \\
\hline
\end{tabular}

Based on table 5 above, validation in stage 1 implemented by skilled teachers in graph feasibility of content/materials, it is found that the average score is $3.18 \%$ with the category of good, while in the validation in stage 2 the average score is $4.45 \%$ with the category of very good. Further explanation about the result of the validation of the skilled teachers and each of the data in both stages is described in the Table below: 
Table 6. Data of Average Score of the Validation of the Skilled Teachers

in Stage 1 and Stage 2

\begin{tabular}{|c|l|c|c|c|c|}
\hline \multirow{2}{*}{ No } & \multirow{2}{*}{ Aspects of Assessment } & $\begin{array}{c}\text { Average Score of the Validation } \\
\text { of the Skilled Teachers in Stage 1 } \\
\text { and Stage 2 t }\end{array}$ & \multicolumn{2}{|c|}{ Category } \\
\cline { 3 - 6 } & $\mathrm{S} .1$ & $\mathrm{~S} .2$ & $\mathrm{~S} 1$ & $\mathrm{~S} 2$ \\
\hline \multirow{2}{*}{1} & $\begin{array}{l}\text { Correspondence in } \\
\text { Content / Materials }\end{array}$ & $3,18 \%$ & $4.41 \%$ & Good & Very Good \\
\hline
\end{tabular}

The table 6 above shows that there is a significant development in Stage 2, compared with that in Stage 1. The average score in Stage 1 is 3.18, with the category of fair, while the average score in Stage 2 is 4.41, with the category of distinction (very good). Therefore, it could be concluded that there is a significant development of validation in Stage 2 compared with that in Stage 1, with the disparity of 1.68. It indicates that there is the development of teaching materials by using a scientific approach after they have been revised.

\section{Conclusion}

The conclusion is that using a scientific approach in the research development of teaching materials in the skill of writing descriptive texts is very effective when it is implemented at SMK (vocational school), especially at SMK Bisnis, UMN Al-Washliyah. The result of the pre-test shows that the lowest average score is $67 \%$. From this average score, it could be concluded that the students are not very interested in the conventional approach. Based on the result of the pre-test, the researchers would like to find out the effectiveness of the scientific approach in developing teaching materials in the skill of writing descriptive texts. After the post-test is done to the students of SMK Binaan UMN Al-Washliyah when they get teaching materials, using a scientific approach, their scores (grades) increases significantly. It could be seen from their average score of $85 \%$ in the post-test. This phenomenon proves that there is the influence of the scientific approach to developing teaching materials in its effectiveness. The level of feasibility in the content of materials is $63.6 \%$ in the pre-test, and they increase to $88.2 \%$ in the post-test; the feasibility of teaching materials in the pre-revision is $0.63 \%$ and increase to $0.85 \%$ in the post-revision. Therefore, it could be concluded that there is an influence of scientific approach to the development of teaching materials in its effectiveness.

It is recommended that students' skill ability in writing descriptive texts be increased. Teachers should develop teaching materials by using a scientific approach in writing descriptive texts so that they will be trained to observe and to identify and formulate problems.

\section{Acknowledgments}

The authors would like to express their sincere appreciation to the Rector of Universitas Muslim Nusantara Al-Washliyah, Medan, who has provided financial support to do this research in the Program of Skema Riset Pengembangan for the year 2019. 
Development of Teaching Materials in Writing Descriptive Texts of Vocational School Students, Risnawaty, Yulia Arfanti, Milisi Sembiring, Roswani Siregar, Heni Subagiharti

\section{References}

Astutik, et all. (2020). The Effectiveness of Collaborative Creativity Learning Models I(CCL) on Secondary Schools Scientific Creativity Skills. International Journal of Instruction July 2020, 13, (3). www.e-iji.net

Bochkareva, et all.( 2020). The Analysis of Using Active Learning Technology in Institutions of Secondary Vocational Education. International Journal of Instruction July 2020 , 13, (3). www.e-iji.net

Indriani, L. (2017). Developing Pre-Service English Teachers' Critical Thinking by Using Academic Journal Writing 4.0. Metathesis: Journal of English Language, Literature, and Teaching, 3(2), 117-123. https://doi.org/10.31002/metathesis.v3i2.1859

Khasanah, A. U. (2019). Teaching Method IN Writing Descriptive Text ( A Descriptive Study at the Seventh Grade Students of SMP Negeri 3 Klaten Academic Year 2016 / 2017 ). $6(1)$.

Kurniasih, K., \& Rahmawati, H. (2018). Developing Writing Materials Based on Eclectic Approach for Indonesian EFL Learners. Metathesis: Journal of English Language, Literature, and Teaching, 2(1), 97. https://doi.org/10.31002/metathesis.v2i1.708

Masrukhah, L. (2017). Developing Learning Descriptive Text Materials tto Support Literacy Skills through DeBeBino Game of the Seventh Grade Students of SMPN 2 Wonoayu. 1(2), 8-15.

Ningsih, A. F., \& Fitrawati. (2014). Teaching Writing a Descriptive Text Through My Story Maker Media. Jelt, 3(1), 64-71.

Palupi, B. S., Subiyantoro, S., Triyanto, \& Rukayah. (2020). Creative-thinking skills in explanatory writing skills viewed from learning behavior: A mixed-method case study. International Journal of Emerging Technologies in Learning, 15(1), 200-212. https://doi.org/10.3991/IJET.V15I01.11487

Risnawaty, Sutikno, Sembiring, M., Andriany, L., \& Siregar, R. (2020). The Translation of Ngangkat Tulan-Tulan texts in Karonese society into English. Talent Development and Excellence, 12(1), 352-361.

Riwayatiningsih, R. (2019). Improving Writing Skill with Questioning: A Path on Critical Thinking Skill. Metathesis: Journal of English Language, Literature, and Teaching, 3(2), 203. https://doi.org/10.31002/metathesis.v3i2.1665

Sarma, Devita. Rosa, Rudi, N. (2014). Teaching Writing a Descriptive Text by Using Double Entry Diary to Junior High School Students. Jelt, 3(September).

Sembiring, Milisi. Panggabean, H. (2018). Translating Culture-Bound Terms in Wedding Speech Texts of Karonese Society into English. SKASE Journal of Translation and Interpretation, 11(1), 69-92.

Silva, J. P. da, \& Silveira, I. F. (2020). A Systematic Review on Open Educational Games for Programming Learning and Teaching. International Journal of Emerging Technologies in Learning (IJET), 15(09), 156. https://doi.org/10.3991/ijet.v15i09.12437

Sugiyono, S. (2016). Metode Penelitian Kuantitatif, Kualitatif,Dan R\&D. Bandung: Alfabeta, CV.

Sundana, G. P. (2017). The Use of Authentic Material in Teaching Writing Descriptive Text. English Review: Journal of English Education, 6(1), 81. https://doi.org/10.25134/erjee.v6i1.773

Syaodih, Sukmadinata, \& Nana. (2009). Pengembangan Kurikulum : Teori dan Praktek. In Journal of Chemical Information and Modeling. https://doi.org/10.1017/СВ09781107415324.004 
Wijaya, R. K. (2017). Students 'Perception of Teachers' Nonverbal Immediacy Behavior toward Students 'Attitude and Motivation in Learning English. 4(1).

Yamin, M. (2019). Learning From Students' Experiences in Writing Paragraphs. Metathesis: Journal of English Language, Literature, and Teaching, 3(2), 188. https://doi.org/10.31002/metathesis.v3i2.1736

Zaim, M. (2017). Implementing Scientific Approach to Teach English at Senior High School in Indonesia. Asian Social Science, 13(2), 33. https://doi.org/10.5539/ass.v13n2p33 